\title{
SITUAÇÕES COLONIAIS, PLURALISMO ÉTNICO E DESAFIOS DA AUTONOMIA INDÍGENA NA AMÉRICA LATINA
}

Cristhian Teófilo da Silva Universidade de Brasília, CEPPAC

\section{Introdução}

No dia cinco (5) de junho de 2009, em uma localidade chamada "El Reposo” próxima a Bagua no Departamento do Amazonas, Peru, se concentravam milhares de pessoas dos povos indígenas Aguarunas e Huambishas além de outros grupos étnicos e moradores rurais, para protestar contra decretos que favoreciam a exploração de recursos hídricos, minerais, florestais e de petróleo na amazônia peruana. O protesto em curso há mais de 50 dias, e que comprometia o abastecimento de diversas comunidades e cidades, consistia no bloqueio da estrada nomeada em homenagem ao ex-presidente progressista "Fernando Belaúnde Terry”, também denominada “vía Marginal de la Selva” que interliga o Equador, Peru, Colômbia e Venezuela. Esta situação acarretou um embate violento entre manifestantes e forças policiais que resultaram em dezenas de mortos e centenas de feridos conferindo ao episódio o nome de "masacre de Bagua”.

Durante o desenrolar dos protestos o presidente peruano Alan García apresentou sua opinião em programa de televisão sobre a resistência dos indígenas e camponeses aos decretos:

"Ya está bueno. Estas personas no tienen corona, no son ciudadanos de primera clase. 400 mil nativos no pueden decirnos a 28 millones de peruanos: tú no tienes derecho de venir por aquí. De ningunamanera,esoesunerrorgravísimoyquienpiensedeesamaneraquierellevarnosalairracionalidad y al retroceso primitivo en el pasado”. (Declaraciones de García respecto al conflicto de Bagua: http://www.youtube.com/watch?v=yjzxl1lBswcer, site consulté le 8 novembre 2013)

"En fin, volver a esas formas primitivas de religiosidad donde se dice no toques ese cerro porque es un Apu y está lleno del espíritu milenario y no sé qué cosa ¿no? Bueno si llegamos a eso entonces no hagamos nada ni minería, no toques esos peces porque son criaturas de dios y son la expresión del dios Poseidón. Volvemos a digamos... a este animismo primitivo ¿no? yo pienso que necesitamos más educación, pero eso es un trabajo de largo plazo eso no se arregla así”. (Declaraciones de García respecto al conflicto de Bagua: http://www.youtube.com/watch?v=yjzxl1lBswcer, site consulté le 8 novembre 2013)

Na esteira de episódios como o conflito de Bagua ou, mais recentemente, em torno da construção da hidrelétrica de Belo Monte no estado brasileiro do Pará, e no rastro de sucessivos episódios de violência estatal contra os indígenas, em que movimentos indígenas são policial ou militarmente reprimidos, estudos e reflexões sobre o impacto da democratização e redemocratização na 
América Latina têm examinado a efetividade do multiculturalismo constitucional conceber e implementar direitos para os povos indígenas, tribais e demais grupos étnicos frente aos "interesses nacionais" enunciados nas políticas neoliberais e neodesenvolvimentistas da região. Este artigo pretende contribuir para a crítica ao neocolonialismo expresso nestas situações apontando a vigência de concepções raciais advindas de práticas coloniais no âmbito dos governos e Estados latino-americanos.

Para tanto, este artigo tem o objetivo de apresentar conceitos e noções antropológicos e sociológicos elaborados a partir de situações coloniais e de contato para explicar, a partir deles, a importância da noção de raça para a constituição de sociedades plurais, de maneira geral, e para o exercício do poder estatal sobre os povos indígenas na América Latina, em particular. Este padrão de poder, como espero demonstrar, vem a ser o principal obstáculo à efetivação dos direitos constitucionais dos povos indígenas, definidos que estão nos termos de uma política multicultural de reconhecimento.

Os conceitos e noções que serão mencionados foram elaborados na segunda metade do século XX e decorrem da observação direta de processos de transformação social das populações indígenas submetidas aos processos euro e neocoloniais. Eles serão mencionados para reafirmar o lugar central desempenhado pela noção de raça para se explicar a estruturação das relações entre povos indígenas e administrações coloniais e indigenistas. Estes conceitos, como veremos, foram revisados porque indicam a densidade do envolvimento antropológico e sociológico com o problema do colonialismo em nível mundial tornando, no mínimo contraditória, a recusa etnográfica contemporânea de abordar a racialidade das relações interétnicas no âmbito dos Estados nacionais.

Neste sentido, estes conceitos e noções são emblemáticos do double bind disciplinar constituído diante dos processos de expansão colonial e, posteriormente, de construção nacional ao redor do mundo (L’Estoile, Neiburg e Sygaud 2002. Como se sabe, ao se debruçar sobre o “Savage Slot”, nas palavras de Michel-Rolph Trouillot (1991), as Ciências Sociais e, em particular, a Antropologia, passaram a operar tanto como "saber teórico para” quanto “crítico da” administração colonial, onde o problema, mais que o tema, da mudança das culturas e sociedades indígenas foi posto como um dos principais, senão o principal, desafio teórico compartilhado por diferentes comunidades antropológicas em regiões colonizadas e periféricas à consolidação dos cânones da disciplina.

Dito isto, ao buscar recuperar certos conceitos e noções, este artigo tentará superar este double bind característico ao propor a permanência da raça como categoria ideológica nas estruturas de dominação sobre povos indígenas como problema de pesquisa ao invés de persistir no estudo obsessivo da mudança das/nas etnias (um eufemismo para "raças”) indígenas como objeto. Quer dizer, a ideia não é analisar a "mudança dos índios” do ponto de vista que interessaria à sua melhor intepretação teórica ou à administração indigenista. Também não se pretende reiterar de maneira redundante as volumosas críticas ao poder colonial. O objetivo é criar um referencial conceitual para analisar por quais meios a dominação interétnica configurada nas situações coloniais e de contato se atualiza até os dias atuais na administração e políticas indigenistas dos Estados nacionais na América Latina. 
Do contato ao colonialismo interno, passando por situações coloniais e processos de aculturação: Para reconhecer a racialidade do poder nas relações interétnicas

Iniciarei o trabalho de tessitura conceitual por Bronislaw Malinowski, principal responsável pela disseminação da pesquisa de campo de longa duração como cânone da geração antropológica de conhecimento sobre povos “primitivos” e talvez o pioneiro, a se ocupar das transformações dos "nativos” sob o domínio colonial. É certo que outros antropólogos se ocuparam deste tema, a exemplo de Maurice Leenhardt entre os Kanak, entretanto, foi Malinowski, quem buscou conferir relevância teórica para o problema da mudança de instituições tribais em contextos coloniais.

Isto se deu após duas décadas de publicações bem-sucedidas sobre os habitantes das ilhas Trobriand no Pacífico. Em 1940, Malinowski inicia uma série de publicações dedicadas a sistematizar uma "teoria científica da cultura”. Esta não encontrou a mesma aceitação e impacto que seus trabalhos etnográficos, em larga medida pelo explícito funcionalismo atribuído por ele às instituições sociais na satisfação de necessidades biológicas. Em 1945, seu livro póstumo: "Dynamics of Culture Change” ("Dinâmicas da Mudança Cultural”) dedica-se, especificamente, ao problema da mudança cultural. Neste livro, a "situação de contato" é descrita como uma "totalidade integral” e como uma realidade cultural imediata. Esta abordagem visava se opor ao funcionalismo mais ortodoxo de A. R. Radcliffe-Brown, quem concebia apenas a estrutura social empiricamente observável de povos particulares como o objeto principal da etnografia e da antropologia comparada. Nas palavras de Malinowski: “Já é agora geralmente acordado que os europeus formam uma parte integral de qualquer situação de contato.” (1966 : 11, tradução CTS)

Essa constatação é feita a propósito de reconhecer a mudança cultural como proveniente da própria intervenção colonialista (concebida como “cultura superior” e polo ativo de mudança), do que nos fatores intrínsecos às estruturas sociais e instituições das populações indígenas ou tribais (concebidas como "culturas inferiores" e polo passivo de mudança). A mudança, nesses termos, seria um processo unidirecional de substituições ocorridas no interior das culturas ditas primitivas (Malinowski sempre maximizou o adjetivo) a partir das interações entre europeus e indígenas para a satisfação de suas necessidades funcionais. Nesse sentido, a mudança não poderia ser compreendida tomando apenas um dos segmentos da situação de contato e suas respectivas instituições como referência. Ambos, europeus e indígenas, deveriam ser compreendidos em suas múltiplas, diversas e estáveis interações manifestadas em interações sociais cooperativas, nas quais ambos compartilhariam interesses e intenções. A “cultura do contato”, nesta abordagem seria o resultado da combinação das diferentes maneiras que europeus e indígenas teriam para satisfazer suas necessidades básicas numa data situação de contato.

Na Inglaterra, principal país de difusão antropológica das ideais de Malinowski e, aquela altura, a principal potência imperial europeia, um dos alunos de Radcliffe-Brown e E. E. Evans-Pritchard, mas também de Malinowski, se pôs em declarado desacordo com a descrição das mudanças decorrentes das situações de contato feita por Malinowski, apesar de concordar com este no que tange à necessidade de abordar etnograficamente as dinâmicas de mudança. Max Gluckman, que viria a se tornar 
o primeiro professor de antropologia da University of Manchester, se lançou em uma crítica do que chamou de "análise funcional da mudança social” (não mais “cultural”). Em sua visão, Malinowski acertou ao compreender o caráter compósito da vida tribal imiscuída pela presença colonizadora europeia, porém errou ao conceber esta situação de contato como uma totalidade harmoniosa e cooperativa entre os grupos envolvidos unidos por interesses e intenções comuns, numa clara subordinação da realidade a um fraco modelo teórico (ver Malinowski 1966: 15-16 e Gluckman 1966 : 25-33).

Gluckman procurou apresentar dados etnográficos que evidenciam a limitação teórica de Malinowski para lidar com situações de "compatibilidade, adaptação e conflito”, precisamente aquelas nas quais os interesses indígenas não são satisfeitos. Segundo Gluckman: “Ele (Malinowski) não consegue ver que as minas Rand (por exemplo) são um campo de conflito tanto quanto um campo de cooperação no qual os africanos, pelo dinheiro que desejam, ajudam os europeus a extrair ouro” (Gluckman 1966 : 28, parêntesis adicionados, tradução CTS).

Para Gluckman, ocorre um excessivo esquematismo na elaboração teórica de Malinowski sobre a mudança. O modelo de "três realidades culturais" apresentado por este, compreendendo duas culturas "A" e "B" que entram em contato gerando uma terceira e nova cultura "C", não serve como ferramenta de análise, pois não demonstra, por exemplo, como “A” e "B” interagem entre si, muito menos como "C" - a cultura da mudança - derivaria, na prática, de articulações entre “A” e "B”. Para Malinowski a mecânica do contato se daria por uma espécie de substituição de instituições do "mesmo tipo” em que as funções sacerdotais desempenhadas pelo xamã da tribo, por exemplo, seriam substituídas pelas práticas de sacerdotes cristãos e assim por diante. Para Gluckman, o que deveria ser buscado analiticamente é o estudo de uma situação concebida como a estabilização de eventos interdependentes que ocorrem numa situação “AB”, onde interesses e intenções das partes envolvidas manteriam unidos ao longo do tempo colonizadores e colonizados numa comunidade plural, diferenciada internamente apenas por uma ideológica "linha de cor" que serviria para impor uma hierarquia naturalizada da "superioridade biológica europeia” em detrimento da “inferioridade biológica indígena”. Tratava-se de lidar, portanto, com sistemas racializados de relações interétnicas e intertribais. Gluckman sugere, portanto: “(...) que, para estudar a mudança social na África do Sul, o sociólogo deve analisar o equilíbrio da comunidade africana-branca em diferentes períodos de tempo e mostrar como sucessivos equilíbrios estão relacionados entre si.” (:262)

Nota-se assim, que Gluckman almejou mais uma metodologia do que uma teoria para abordar casos particulares de interação entre grupos que configuram novas situações de equilíbrio a partir de sucessivos embates e conflitos decorrentes das posições estruturalmente distintas e historicamente assimétricas advindas da experiência colonial. Trata-se de considerar a história das relações coloniais como parte dos dados etnográficos para explicar as mudanças. Esta orientação veio a consolidar, precisamente, o "estudo de caso-estendido" (extended-case method), voltado para eventos e processos de cooperação e conflito entre segmentos de grupos culturalmente diversos em contextos coloniais específicos. A "Escola de Manchester”, como veio a ser conhecido o 
grupo de pesquisadores que sob a influência de Gluckman levaram adiante o projeto de realizar estudos etnográficos de "situações coloniais” tornou-se a principal precursora do debate teórico sobre "dramas”, “conflito”, “experiência” e “prática” na Antropologia (ver Evens \& Handelman 2008).

Vemos assim, que para Malinowski e Gluckman as interações, relações e situações criadas por europeus e indígenas ou "brancos" e "africanos" constituem realidades culturais e sociais dinâmicas, observáveis e explicáveis do ponto de vista etnográfico. Se para Malinowksi os processos de mudança cultural decorreriam das adaptações e acomodações pelas sociedades tribais diante da instituições e cultura dos europeus, para Gluckman, este fenômeno constituiria apenas a superfície do problema, cabendo ao antropólogo recorrer à história para apreender o sentido da mudança em termos sociais, i.e., a sociogênese de comunidades plurais que não seriam necessariamente redutíveis a modelos bipolares do tipo “colonizador-colonizado”. Dito de outro modo, vemos nestas duas abordagens que a ideia de raça não aparece como um conceito científico para explicar a realidade, mas como uma categoria engendrada pelos grupos em contato para organizar politicamente suas interações a partir de culturas distintas e postas em contato pelo advento do colonialismo como expansão europeia.

Trata-se de uma concepção da mudança como sucessão de situações de equilíbrio entre grupos que se combinam e reorganizam para fins de manutenção de novos e mais complexos padrões de interação. Desnecessário dizer que este padrão atende aos interesses e anseios dos grupos de maneira extremamente desigual ou assimétrica.

Por mais elegante que seja a teoria da mudança assim elaborada por Gluckman, ele encontrou em seu colega Edmund Leach, um fiel adversário. Leach, também formado no contexto da Antropologia social britânica, publicou seu: "Political Systems of Highland Burma” ("Sistemas políticos da Alta Birmânia”) (1954) após realizar pesquisas na Birmânia como militar do exército britânico na região. Seu objetivo foi desconstruir os modelos interpretativos da "mudança das culturas e estruturas sociais" apoiado justamente na análise das ideologias indígenas e no domínio de suas categorias e modelos de sociedade. Quer dizer, para Leach, antropólogos e nativos pensam e agem segundo concepções idealizadas das sociedades que tomam como objeto de reflexão e ação. A suposta situação de equilíbrio de forças visada pelo antropólogo não passaria de uma ficção que contaria com a cumplicidade de seus interlocutores para sua idealização.

Enquanto desempenhava seu duplo objetivo - qual seja, o de proporcionar uma etnografia das populações Kachin e Shan do nordeste da Birmânia e problematizar as ficções da teoria antropológica, Leach nos proporciona uma importante contribuição para uma "antropologia da inconsistência dos sistemas sociais”. Neste trabalho, ele amplia o campo de observação e reflexão da Antropologia Social, na medida em que reconhece diferentes níveis de complexidade que compõem os sistemas sociais, implementados pelos processos históricos que dispõem segmentos populacionais em arranjos diversos organizados no tempo e no espaço. Para Leach, tais processos, com seus respectivos arranjos, diluem os contornos das sociedades através da instabilidade das estruturas sociais fazendo da história, redefinida assim em termos 
mais heraclitianos - do tipo "tudo flui, tudo se transforma” - e menos eleáticos - do tipo "o movimento é uma sucessão de paradas” (Elias 1993), condição para uma análise antropológica da mudança social.

É preciso reconhecer que o próprio campo empírico da pesquisa demandava do pesquisador uma alta capacidade de observação. A contribuição de Leach, motivada por uma oposição teórica-metodológica às ideias de Gluckman, reside precisamente nesta reelaboração da análise antropológica da mudança fundamentada na análise dos processos sociais e históricos, mais do que nas trocas culturais ou situações sociais estáticas e em equilíbrio. Parte de sua originalidade analítica, portanto, se deve ao fato do seu campo não ser um lugar comum do colonialismo. As montanhas Kachin compreendem um contexto com uma população de dezenas de milhares de pessoas, falantes de quatro grandes grupos linguísticos, onde a identificação e auto-identificação de pessoas e grupos a “etnias” ou “tribos” é variável entre modelos de comportamento político (Gumsa, Gumlao e Shan) e intercambiável ao longo do tempo e regulado por um regime próprio de obtenção de poder e prestígio e transmissão de direitos políticos e territoriais (o sistema Mayu-Dama). Ou seja, não se tratava de falar de um "povo” ou “tribo", possuidor de uma única “estrutura social” que se autoperpetua em equilíbrio até ser obrigada a mudar por força de uma “cultura superior” e dominante. Tratava-se de interpretar estruturas em "equilíbrio dinâmico” com todas as contradições que esta concepção promove como forma de representação do mundo social colonial.

Tal "contingência” ou singularidade do campo de pesquisa (mais do que do povo estudado) aliada à ambição de consolidar seu "nome” no campo da antropologia social inglesa (cf. Sigaud, 1996: 29 op. cit.) ofereceu a Leach a "oportunidade” de questionar justamente o problema: “(...) of how far it can be mantained that a single type of social structure prevails throughout the Kachin area.” (Leach, 1993: 03) Leach não encontrou formas fixas de comportamento social no interior de estruturas sociais estáveis.

O duplo posicionamento teórico de Leach, entre um empirismo (influência da tradição antropológica britânica) e um racionalismo (influência de sua leitura das "Estruturas elementares do parentesco" de Lévi-Strauss), possibilitaram uma polarização entre uma abordagem "individualizante” e outra "totalizante” ou "sistêmica” (influenciada pela sociologia de Pareto, Weber e Talcott Parsons). Ao aspirar por uma teoria dinâmica da sociedade em forte oposição ao estrutural-funcionalismo, Leach acaba por promover o indivíduo de sua condição de ator social na estrutura à agente social das estruturas. Os indivíduos (indígenas e antropólogos) criam suas próprias ideias acerca da realidade social em que estão inseridos como se esta operasse segundo os parâmetros de sua concepção. É esta realidade como se que os indígenas tentam vivenciar no cotidiano e que o antropólogo deve discernir através do contraste entre o comportamento social real e o comportamento social ideal. Para tanto, a perspectiva teórica de Leach tende a privilegiar os indivíduos como os responsáveis pelas mudanças sociais, segundo uma "pauta estrutural subjacente” que governa sua direção. Não se trata mais de pessoas comuns, mas de ambitious seekers of power.

Leach propõe assim uma nova concepção de estrutura social centrada nas disputas e competições por poder e prestígio (power structures) que permeia os sistemas políticos. As formas de 
pertencimento de indivíduos a grupos políticos determinados são enfocadas justamente quando membros de um sistema estrutural dinâmico encontram-se calculando estrategicamente suas posições neste sistema. Nestes termos, a integração dos sujeitos étnicos à estrutura de poder é política e não cultural (Sigaud, 1996: 35) e a cultura, como depois sistematizou Barth (2000 [1969], passa a ser definida como o resultado de um processo de organização social da diferença entre pessoas e grupos que se identificam e identificam aos outros em função de processos de colaboração, competição e conflito por recursos. Chega-se assim a uma teoria situacional da etnicidade, segundo a qual identidades coletivas são construídas ideologicamente para fins de organização política e jurídica de interesses e objetivos contraditórios, porém interdependentes para sua realização. O uso de concepções raciais nestes contextos apenas expressa uma forma particular de valorizar características fenotípicos distintivas de certos indivíduos e populações para fins de categorizá-los numa dada estrutura de distribuição do poder.

Importante assinalar aqui que Leach não se comprometeu em analisar as dinâmicas sociais indígenas em interação com sujeitos e agências coloniais. Sua abordagem e teoria constituem contribuições importantes para a análise do poder na estruturação das relações sociais, mas não necessariamente do poder colonial sobre as instituições nativas.

De Malinowski a Leach percorremos conceitos, noções, abordagens e teorias que procuram lidar com os aspectos funcionais ou estruturais do contato e da mudança. Este itinerário conceitual não foi o único a ser desenvolvido pela Antropologia. A ênfase que antropólogos formados na Inglaterra davam às estruturas sociais não era compartilhada, por exemplo, por seus colegas nos Estados Unidos. Neste país, Franz Boas e seus alunos, muitos deles da América Latina, do Caribe e do Canadá, dedicavam-se à pesquisa etnográfica de "salvamento" das culturas e línguas indígenas em franco desaparecimento decorrente do “contato” predatório com “culturas estrangeiras”. Boas e seus alunos reelaboraram o conceito de cultura de modo a conferir a ele um dinamismo, relativismo e particularismo (ver Stocking 1968) acionado etnograficamente até os dias de hoje.

A maior contribuição teórica e metodológica de Boas, portanto, assim como Malinowski, foi ter se oposto ao pensamento difusionista alemão e ao evolucionismo linear que prevaleceu no século XIX tanto nos EUA quanto na Inglaterra e França em prol de uma perspectiva mais etnográfica sobre cada povo ou áreas culturais específicas. Para isso, valeu-se do bildung característico da formação acadêmica alemã, onde se conjugava um forte humanismo intelectualista a um rigoroso treinamento empirista em ciências exatas (ver Silva 2003). É no interior dessa dupla tradição epistemológica que se desenvolveu um programa metodológico forte entre Antropologia e História a partir de abordagens comparativas de processos culturais (ver também Schwarcz 2005).

Boas também foi combativo do racismo científico prevalecente na academia estadunidense em fins do século XIX e início do século XX. A partir de uma série de estudos em antropologia física, Boas demonstrou que as diferenças culturais entre pessoas e grupos não 
decorriam de características hereditárias, mas de comportamentos adquiridos pela tradição e a cultura.

As orientações de Boas para o estudo da história das culturas foram conformadoras da escola de “Cultura e Personalidade” nos anos 1930 nos EUA. Nessa “escola”, Gregory Bateson, Margareth Mead, Ruth Benedict e outros antropólogos, psicólogos, linguistas etc., contribuíram para problematizar as relações entre indivíduo e sociedade e seus impactos na formação da personalidade de pessoas e povos através de processos de socialização que acompanham os indivíduos desde a infância até sua morte. Derivaram daí as interpretações “desviantes”, “patológicas” e “anômicas” para o comportamento dos indígenas diante do ocaso de suas sociedades face à dominação colonial e, posteriormente, nacional.

Da cultura à aculturação, a antropologia estadounidense tratava a mudança como um processo de socialização (mal realizado e incompleto) das culturas indígenas pelas culturas dominantes. Na verdade, em um cenário no qual aproximadamente quatro milhões de indígenas, no início do século XVI, foram reduzidos a menos de um milhão no início do século XX, os estudos realizados a partir de então passaram a enfocar comunidades indígenas como "ilhas culturais" em desaparecimento na paisagem americana (Jarvenpa 1985 : 30). ${ }^{\mathrm{i}}$

A abordagem de Boas e sua escola à mudança, na verdade, deve ser compreendida como uma abordagem avessa ao tema. O foco do "culturalismo" estadunidense recaiu mais sobre a permanência e os traços institucionais distintivos das culturas indígenas do que sobre os processos de sua fragmentação, transformação ou desaparecimento. Como observou Trigger a respeito da objeção de Boas ao estudo da mudança: “Anthropologists treated such changes as impediments to the study of traditional cultures, and often ethnologists simply tried to ignore them, as Franz Boas did when he deleted sewing machines and other obviously modern devices from his descriptions of West Coast potlaches”. (1985: 19).

Foi o "Memorandum for the study of acculturation" (1936) elaborado por Robert Redfield, Ralph Linton \& Melville Herskovits, em resposta às demandas do Social Sciences Research Council (SSCR), que buscou justamente indicar uma nova metodologia para preencher esta recusa etnográfica ao estudo da mudança (a esta altura um eufemismo para “dominação”) junto aos povos indígenas. Esta metodologia implicava a preocupação com a simetria e a dominação social e política nas relações entre grupos distintos para fins de análise dos resultados da aculturação, nomeadamente: aceitação, adaptação e reação.

Sendo assim, é importante assinalar que mesmo sob distintos paradigmas, a Antropologia iniciou estudos sobre a “mudança” e a “aculturação” das populações indígenas como processos pautados por relações assimétricas de poder e dominação entre grupos postos em uma situação irreversível de contato. Esta irreversibilidade da colonização conjugada à inevitabilidade de se lidar com o poder e o terror do colonialismo suscitou críticas e autocríticas antropológicas às políticas de integração das populações indígenas às sociedades nacionais segundo políticas de assimilação "harmoniosa”, "humanitária”, "progressista”, “positivista” etc. Como se sabe, até este momento, Antropologia (aplicada) e indigenismo (de Estado) haviam se tornado um par inseparável para a realização das políticas de integração empreendidas junto aos povos 
indígenas até meados do século XX (Oliveira Filho \& Souza Lima 1983). A prática política e crítica social ao colonialismo e ao imperialismo proveniente de intelectuais (filósofos, psicanalistas, literatos e cientistas sociais, principalmente) com forte inspiração anti-colonialista foi determinante de um novo impulso teórico e crítico na disciplina face ao racismo e aos estereótipos coloniais produzidos a respeito do “índio".

Nesta direção, um importante inspirador da guinada crítica ao colonialismo e às teorias da mudança social, cultural e da aculturação foi George Balandier a partir de seu conhecido artigo: "La Situation Colonial: Approche Théorique” (“A situação colonial: Abordagem teórica”) (1951 e 1966). Balandier reconheceu o caráter irreversível e inevitável da presença colonizadora europeia para a compreensão do "problema colonial” do ponto de vista das populações colonizadas. Seu artigo começa afirmando, malinowskianamente, que: "Um dos eventos mais surpreendentes da história recente da humanidade é a expansão dos povos europeus ao redor de todo o mundo” (1966 : 34, tradução CTS).

Muito além de simples fenômeno demográfico e geográfico, esta expansão surpreende por suas implicações políticas e econômicas, em especial pela difusão do colonialismo como um regime de dominação razoavelmente uniforme em sua lógica de subordinação de populações e territórios diversos, compreendendo cerca de $1 / 3$ da superfície do planeta ao longo dos últimos quinhentos anos.

Apoiado no trabalho seminal de Octave Mannoni sobre a psicologia da colonização e de quem apreende a noção de "situação colonial”, Balandier busca analisar o tipo especial de situação, na qual os povos subjugados foram redefinidos e até inventados, numa autêntica obra de engenharia social, por sucessivas administrações coloniais.

Partindo dos estudos coloniais levados a termo por historiadores, economistas, geógrafos, antropólogos e psicólogos à época, e tomando a África como continente colonial par excellence, Balandier elaborou, de modo similar a Gluckman, uma concepção operacional de "situação" com vistas a analisar a interação e articulação de três esferas recorrentes na história da expansão colonialista, notadamente as esferas econômica, política e religiosa. Em suas palavras: “Os objetivos econômicos, governamentais e missionários foram experimentados pelos povos subjugados como atividades estreitamente associadas, e foi nos termos desses fatores que os antropólogos costumeiramente analisaram as 'mudanças sociais'." (Balandier 1966 : 39, tradução CTS).

Sob essa perspectiva, a “situação colonial” emerge como um complexo único, uma situação de dominação de proporções totais (e virtualmente, totalitárias). Porém, diferente de Malinowski e apoiado nas críticas de Gluckman, Balandier não concebe esse caráter total da situação colonial como um todo harmonioso e integrado, no qual as mudanças seriam uma sucessão de situações em equilíbrio. Para ele, a situação colonial decorre de processos em que grupos diferentes, conscientes de sua distinção étnica perante os demais, organizam sua relação para fins de exploração e exercício do poder, conformando sociedades plurais. Não se trata, tão somente, de processos de "produção social da 
diferença cultural”, mas da produção histórica da subordinação colonial, isto é, um padrão de relação de poder que possui a capacidade de se transformar em uma nova forma de estrutura social de dominação.

\section{Segundo esta concepção:}

“O fato interessante não é a existência do pluralismo (uma característica de qualquer sociedade global), mas a indicação de suas características específicas: a base racial dos 'grupos', sua extrema dessemelhança, o caráter antagonístico das relações que estabelecem entre si, e a necessidade imposta a eles de coexistirem 'nos limites de uma mesma estrutura política’”. (idem: 45, parêntesis no original, tradução CTS)

Daí decorre a estrutura assimétrica das relações entre colonizadores e colonizados nas sociedades plurais. Ela implica uma interdependência, segundo a qual os colonizados perdem, efetivamente, sua autonomia, que passa a ser gerada e administrada pelos colonizadores, segundo os termos morais e jurídicos destes. Passamos assim, da “mudança” como questão antropológica à “dominação” como questão política. A nova sociedade plural é uma sociedade hierarquizada racialmente, de modo a que indivíduos e grupos sejam posicionados segundo sua maior ou menor proximidade de traços, costumes e valores do grupo dominante, no caso, europeus com vistas a melhor servir aos interesses e modos de exploração destes últimos. O cúmulo da violência colonial é a justificativa desta dominação como forma de "melhorar”, “civilizar” ou fazer "progredir” os nativos.

Quer dizer, nestes termos, que o problema sociológico fundamental em sociedades plurais é o modo como os colonizadores conseguirão impor sua visão do mundo social, seus objetivos, seus meios de exploração etc., sobre uma população etnicamente diversa e no âmbito de um novo regime de dominação, no qual os primeiros são numericamente inferiores aos últimos. Dito de outro modo, estamos diante da reelaboração do "problema colonial” como uma questão de integração, do ponto de vista sociocultural e econômico, e de legitimação do poder, de um ponto de vista político e jurídico.

É precisamente o “problema colonial” de manter o exercício do poder em prol de uma integração sociocultural que favoreça a expansão e exploração econômica da colônia que é redefinido na América Latina pós-colonial como o "problema do desenvolvimento" ou do "subdesenvolvimento" nacional. Os estudos econômicos latino-americanos, a exemplo da Comisión Económica para América Latina y el Caribe (CEPAL), dedicaram-se precisamente a formular uma nova doutrina econômica para os países da região com o propósito de alavancar seu desenvolvimento, definido como "crescimento econômico de base industrial”, a exemplo das sociedades capitalistas modernas. Esta doutrina visava promover, através do protagonismo do Estado nacional, uma política de industrialização dirigida com vistas à substituição das importações, o que veio a ser designado como "nacional-desenvolvimentismo". Esperava-se que esta política superasse os impasses e dificuldades que bloqueavam o desenvolvimento periférico como a industrialização espontânea, a baixa elasticidade-renda dos produtos primários, 
o excesso de força de trabalho rural nos países periféricos, as políticas protecionistas dos países centrais etc. Entretanto, mais importante que deter-se na doutrina, é a compreensão da realidade latino-americana que lhe serve de base que nos interessa apreender neste momento. Esta compreensão nos ensina que:

“Os problemas que levavam a América Latina e a periferia ao atraso derivavam de heranças históricas, como a colonização, e decisões internas equivocadas que beneficiavam grupos parasitários em detrimento da nação. Estes países, ao assumirem sua condição nacional, deveriam superá-los e corrigi-los. Essa retificação não implicava um choque com estruturas internacionais, mas sim com grupos sociais e mentalidades internas. Se tratava de superar uma especialização produtiva que a longo prazo se revelou deletéria, de subordinar o tradicionalismo, ou de controlar pela austeridade as tentações ao consumo que a escassez impulsionava. As soluções variavam tal como o diagnóstico, mas tinham em comum o fato de que significavam o desenvolvimento do poder de decisão nacional: sejam elas as políticas de substituição de importação; ou a reivindicação do capital estrangeiro, visto como um recurso auxiliar, mas necessário, em maior ou menor medida, à formação e expansão da poupança e da renda nacional. A implementação destas soluções levaria à convergência com os padrões econômicos, políticos e sociais dos países centrais e ao desenvolvimento. O subdesenvolvimento se explicava por um atraso na formação das dimensões econômicas, políticas, sociais e culturais que constituíam a nacionalidade, as quais uma vez estabelecidas implicavam o desenvolvimento.” (Martins 2006:170-171)

Neste contexto, foi da combinação entre projetos de construção nacional e problemas teóricos acerca da mudança social e cultural das populações indígenas que se originou o principal traço distintivo das “antropologias periféricas” na região ça” não foram simplesmente aplicadas a partir de suas elaborações europeias ou norte-americanas, mas transformadas para se adequar às particularidades interétnicas latino-americanas e aos propósitos de construção nacional.

Conceitos de “colonialismo interno” (González Casanova 1963); “regiones de refugio” (Aguirre Beltrán 1991 [1967]), “fricção interétnica” (Cardoso de Oliveira 1981 [1964]), "transfiguração étnica” (Ribeiro 1970 - lembrando que seus estudos foram realizados nos anos 50) e "etnodesenvolvimento" (Bonfil Batalla et. al. 1982), por exemplo, expressam o intenso e articulado trabalho intelectual promovido por antropólogos latino-americanos diante dos processos de mudança, discriminação e exploração a que estavam submetidos os indígenas na região desde o período colonial até a segunda metade do Século XX, período de intensificação das frentes de expansão econômica do capitalismo sobre territórios indígenas. Infelizmente, tais estudos não parecem ter tido qualquer impacto sobre os estudos sociológicos e econômicos que visavam examinar o problema do desenvolvimento e da dependência na região, talvez porque estes estudos estivessem mais interessados em pensar apenas as relações de poder entre países no âmbito do sistema mundial a partir dos grupos considerados “dinâmicos” e "hegemônicos” da sociedade, sem considerar a dominação que estes mesmos grupos exercem sobre outras sociedades do mesmo país. 
Segundo Roberto Cardoso de Oliveira (1998 p. 41), o binômio colonialismo - colonialismo interno foi decisivo para a mudança de foco da investigação monográfica sobre tal ou qual etnia.iii Para ele:

“A genealogia do conceito de ‘colonialismo interno’ pode ser traçada, a partir de autores como Gunnar Myrdal e C. Wright Mills, alcançando sua formulação latino-americana mais consistente com Pablo Casanova, em seu artigo de 1963, 'Sociedad plural, colonialismo interno y desarrollo’ (América Latina, año 6, $\mathrm{n}^{\circ}$ 3) ou em seu livro Sociologia de la explotación, no Capítulo ‘El colonialismo interno’.” (Cardoso de Oliveira 1998 : 41)

González Casanova buscava em sua conceituação rechaçar a ideia de que o colonialismo se dava apenas em escala internacional, i.e., compreendendo as relações entre metrópoles e colônias. De modo semelhante a Balandier, González Casanova defendia que o colonialismo também: "se dá no interior de uma mesma nação, na medida em que há nela uma heterogeneidade étnica, em que se ligam determinadas etnias com os grupos e classes dominantes, e outras com os dominados” (1965 apud González Casanova 2007, s/p).

Nesse sentido, o colonialismo interno ocorre no terreno econômico, político, social e cultural e ao longo da história do Estado-Nação e do capitalismo mundial responsáveis, ambos, pelo neocolonialismo que se organiza de modo próprio no plano internacional. Mais uma vez, estamos diante de uma reelaboração da noção de "situação”. Para González Casanova, a situação de dominação em que se encontram os povos subordinados pelo colonialismo interno está ligada ao passado de conquista e colonização em que as populações indígenas, que não foram exterminadas, passaram a fazer parte, primeiro, da situação colonial e depois do Estado nacional que adquire uma independência formal.

Nesta nova conjuntura histórica:

“Os povos, minorias ou nações colonizadas pelo Estado-nação sofrem condições semelhantes às que os caracterizam no colonialismo e no neocolonialismo em nível internacional: 1) habitam em um território sem governo próprio; 2) encontram-se em situação de desigualdade frente às elites das etnias dominantes e das classes que as integram; 3) sua administração e responsabilidade jurídico-política concernem às etnias dominantes, às burguesias e oligarquias do governo central ou aos aliados e subordinados do mesmo; 4) seus habitantes não participam dos mais altos cargos políticos e militares do governo central, salvo em condição de 'assimilados'; 5) os direitos de seus habitantes, sua situação econômica, política social e cultural são regulados e impostos pelo governo central; 6) em geral os colonizados no interior de um Estado-nação pertencem a uma 'raça' distinta que domina o governo nacional e que é considerada 'inferior', ou ao cabo convertida em um símbolo 'libertador' que forma parte da demagogia estatal; 7) a maioria dos colonizados pertence a uma cultura distinta e não fala a língua 'nacional'.” (González Casanova 2007, s/p). 
Desse modo, e diferente da conceituação de “situação colonial” anteriormente vista:

“A agregação do adjetivo ‘interno’ à noção de colonialismo cria, a rigor, um novo conceito, uma vez que retém, por um lado, parte das características das relações coloniais, como as de dominação política e de exploração econômica do colonizador sobre a população colonizada; por outro, acrescenta uma dimensão inteiramente nova. Essa dimensão envolve o que se poderia denominar um novo 'sujeito epistêmico'. E se estivéssemos interessados em discernir alguma coisa parecida com uma 'categoria teórica' como característica da antropologia latino-americana, aquilo que vai se impor com mais vigor é precisamente a dimensão do sujeito cognoscitivo. Não mais um estrangeiro, alguém que observe de um ponto de vista - ou horizonte - constituído no exterior, porém, agora, um membro de uma sociedade colonizada em sua origem - depois transformada em uma nova nação -, um observador eticamente contrafeito de um processo de colonização dos povos aborígenes situados no interior dessa mesma nação. Portanto, do ponto de vista desse observador interno de uma sociedade que reproduz mecanismos de dominação e de exploração herdados historicamente, o que subsiste não poderá ser apenas o deslocamento de um conceito metropolitano - e colonial -, sem repercussões na própria constituição desse ponto de vista. Tratar-se-ia, antes, de um ponto de vista diferente, significativamente reformulado, no qual a inserção do observador - isto é, do antropólogo como cidadão de um país fracionado em diferentes etnias - acaba por ocupar um lugar como profissional da disciplina na etnia dominante, cujo desconforto ético só é diluído se passar a atuar - seja na academia, seja fora dela - como intérprete e defensor daquelas minorias étnicas.” (idem : 42)

Sob o marco deste novo sujeito epistêmico, elaborou-se as noções de "fricção interétnica” e "etnodesenvolvimento”, respectivamente por Cardoso de Oliveira e Rodolfo Stavenhagen (1985), ainda que Guillermo Bonfil Batalla tenha sido precursor na apresentação desta segunda noção. Reproduzirei a seguir a síntese dos dois conceitos apresentada por Cardoso de Oliveira (1998) por considerá-la exemplar na elucidação dos dois conceitos no movimento de transculturação dos estudos coloniais para a América Latina:

“Comecemos pelo conceito de fricção interétnica. Esse conceito - que tive oportunidade de propor em 1962, quando elaborei o projeto ‘Estudo de áreas de fricção interétnica do Brasil’, para o então Centro Latino-Americano de Pesquisas em Ciências Sociais, órgão associado à Unesco e com sede no Rio de Janeiro - teve sua origem em uma reflexão sobre a noção de 'situação colonial’, a que já me referi, na forma como foi desenvolvida por Balandier. Escrevi então:

Chamamos 'fricção interétnica' o contato entre grupos tribais e segmentos da sociedade brasileira, caracterizado por seus aspectos competitivos e, no mais das vezes, conflituais, assumindo esse contato proporções 'totais', isto é, envolvendo toda a conduta tribal e não-tribal que passa a ser moldada pela situação de fricção interétnica. 
Um número razoável de publicações - entre livros, artigos, dissertações e teses - valeu-se desse conceito, revelando sua utilidade, quer no Brasil, quer em outros países latino-americanos. A formulação do conceito significava, em primeiro lugar, uma atitude crítica frente a abordagens correntes na época no Brasil, como aquelas que focalizavam os processos de ‘aculturação' ou de 'mudança social', inspirados, respectivamente, nas teorias funcionalistas norte-americanas ou britânicas. Em segundo lugar, significava um deslocamento do foco das relações de equilíbrio e das representações de consenso para as relações de conflito e para as representações de dissenso. Em terceiro lugar, ainda que de maneira incompleta, propunha que se observasse mais sistematicamente a sociedade nacional em sua interação com as etnias indígenas, como elemento de determinação da dinâmica do contato interétnico. Com isso, apropriávamo-nos da noção de situação colonial, apresentada por Balandier, para transformá-la em conceito adequado para desvendar a realidade das relações entre índios e alienígenas (sic), que se mostraria especialmente fecundo para dar conta de situações de contato entre segmentos nacionais e grupos tribais existentes em território brasileiro, com possibilidade de ser útil quando aplicado em outras regiões da América Latina.

Já com relação ao conceito de etnodesenvolvimento - formulado de maneira bastante consistente por Rodolfo Stavenhagen, em seqüência da 'Reunión de Expertos sobre Etnodesarrollo y Etnocidio en América Latina’ promovida pela Unesco e pela Flacso, em San José de Costa Rica, em dezembro de 1981 - cabe destacar que esse conceito não era apenas um desdobramento do conceito de desenvolvimento, corrente na literatura econômica e política produzida na Europa e nas Américas, mas quase um contra-conceito, uma vez que implicava uma crítica substantiva às teorias desenvolvimentistas, bastante em voga nos países do nosso hemisfério. Com esse conceito, propunha-se uma natureza de desenvolvimento 'alternativo', que respeitasse os interesses dos povos ou das populações étnicas, alvo dos chamados 'programas de desenvolvimento'. Stavenhagen apresenta um elenco de seis consideranda para justificar a adoção do conceito como instrumento capaz de atender à especificidade dos povos do Terceiro Mundo diante da questão do progresso e da modernização:

- que as estratégias de desenvolvimento sejam destinadas prioritariamente ao atendimento das necessidades básicas da população e para a melhoria de seu padrão de vida, e não à reprodução dos padrões de consumo das nações industrializadas, propugnados, exclusivamente, pelo crescimento econômico;

- que a visão seja endógena, orientada assim para as necessidades do país mais do que para os sistema internacional;

- que não se rejeite a priori as tradições culturais, mas que se procure aproveitá-las;

- que se respeite o ponto de vista ecológico;

- que seja auto-sustentável, respeitando, sempre que possível, os recursos locais, sejam eles naturais, técnicos ou humanos; 
- que seja um desenvolvimento participante, jamais tecnocrático, abrindo-se à participação das populações em todas as etapas de planejamento, execução e avaliação.” (Cardoso de Oliveira 1998 : 46, 47 e 48, itálicos no original)

Como se pode notar, a guinada anti-colonialista propiciada pelos estudos antropológicos para pensar a realidade de contato interétnico na América Latina foi decisiva para a elaboração de conceitos que abordassem o caráter assimétrico, conflitivo e total das mudanças acarretadas para os povos indígenas na região. Todos os autores mencionados concordam que os padrões de exercício do poder sobre os povos indígenas foram herdados dos regimes coloniais pelos Estados nacionais na América Latina, engendrando sociologicamente situações virtualmente disruptivas das instituições tribais e indígenas com vistas a sua subsunção política em sistemas de exploração econômica articulados em nível mundial (Wolf 1982).

Entretanto, mais aquém de problematizar a situação colonial imposta aos povos indígenas, o que se buscava era construir formas de superação dessa situação, em particular de suas manifestações contemporâneas decorrentes de planos, projetos e programas nacionais “desenvolvimentistas”, como a noção de etnodesenvolvimento demonstra. ${ }^{v}$ Não se examinou, portanto, como os Estados nacionais criaram instituições para promover a “colonização”, a “integração”, o “desenvolvimento” etc. As etnografias das administrações indigenistas enquanto agências de "anti-conquista”, a exemplo do trabalho de Ponting e Gibbins (1980), no contexto canadense ou de Souza Lima (1995) no contexto brasileiro, ainda são escassas e esporádicas.

Neste sentido, por mais que noções e conceitos de “colonialismo interno", "fricção interétnica”, "etnodesenvolvimento" etc., tenham um evidente ar de familiaridade decorrente do diálogo com as teorias da mudança e da aculturação, assim como com a noção de situação colonial de Balandier, estas estruturas de dominação concebidas pelos antropólogos latino-americanos para lidar com realidades específicas não chegaram a formalizar uma teoria da dominação interétnica, seja para explicar o padrão de poder exercido sobre as populações indígenas para administrá-las e a seus territórios em situações distintas, seja para explicar as formas de reelaboração cultural acionadas pelas populações indígenas em resposta a este poder (ver Silva 2012). Tampouco, ampliaram a escala de análise para enfrentar a dimensão mundial deste padrão de dominação. Penso que esta desatenção se deve à baixa consideração à raça como dispositivo ideológico de dominação, sempre presente nos estudos antropológicos sobre a mudança e a aculturação, o que explica, em parte, este "ponto cego" das teorias do contato. Outra justificativa, refere-se à apropriação e ressignificação da "raça” como categoria contra-hegemônica por intelectuais e movimentos afro-latinos e afro-caribenhos. Isto tem feito da "raça” uma categoria ideológica associada na maioria das vezes à população afro-descendente ou negra, quando na verdade ela é aplicada como racismo a todos os demais segmentos não-brancos das sociedades latino-americanas.

O sociólogo Aníbal Quijano talvez seja quem mais esteja colaborando, recentemente, para superarmos esta lacuna. ${ }^{\mathrm{vi}}$ Quijano se deteve nos aspectos propriamente antropológicos da herança colonial dos Estados latino-americanos a partir da atenção dispensada, a exemplo de Balandier, às classificações 
raciais como taxonomias imprescindíveis ao exercício do poder por minorias de brancos ou criollos sobre indígenas e mestiços subalternos, não apenas em nível nacional, como também global. Em suas palavras:

“Um dos eixos fundamentais desse padrão de poder é a classificação social da população mundial de acordo com a idéia de raça, uma construção mental que expressa a experiência básica da dominação colonial e que desde então permeia as dimensões mais importantes do poder mundial, incluindo sua racionalidade específica, o eurocentrismo”. (2005a p. 227, itálicos no original)

Dito de outro modo, Quijano detém-se na subjetivação da experiência colonial e seus principais produtos:

“1) La 'racialización’ de las relaciones entre colonizadores y colonizados. (...)

2) La configuración de un nuevo sistema de explotación que articula en una única estructura conjunta a todas las formas históricas de control del trabajo o explotación (esclavitud, servidumbre, pequeña producción mercantil simple, reciprocidad, capital), para la producción de mercaderías para el mercado mundial, en torno de la hegemonía del capital, lo que otorga al conjunto del nuevo sistema de explotación su carácter capitalista.

3) El eurocentrismo como el nuevo modo de producción y de control de subjetividad - imaginario, conocimiento, memoria - y ante todo del conocimiento. (...)

4) Finalmente, el establecimiento de un sistema nuevo de control de la autoridad colectiva, en torno de la hegemonía del Estado - Estado-Nación después del siglo XVIII - y de un sistema de Estados, de cuya generación y control son excluidas las poblaciones 'racialmente' clasificadas como ‘inferiores'.” (Quijano, 2005b p. 15-16)

Seguindo essas premissas, Quijano elabora seu conceito de “colonialidade do poder”, que segundo ele, começou a se constituir há cinco séculos, tornando-se mundialmente hegemônico desde o século XVIII. Segundo este novo "padrão de poder" surge o paradoxo constitutivo das atuais sociedades americanas, qual seja: estados independentes articulados a sociedades coloniais. Quer dizer:

“(...) el nuevo Estado Independiente en esta América (Latina), no emergia como um moderno Estado-nación: no era nacional respecto de la inmensa mayoría de la población y no era democrático, no estaba fundado en, ni representaba, ninguna efectiva ciudadanía mayoritaria. Era una ceñida expresión de la colonialidad del poder”. (idem: p. 19, parêntesis no original)

É assim que "raça” nos sistemas interétnicos coloniais e pós-coloniais latino-americanos ganha uma densidade maior como categoria organizadora das relações entre colonizadores e colonizados, uma vez que as populações indígenas serão vistas como um segmento étnico-racial a partir de dois registros: 
1) como populações racialmente inferiores (os "negros da terra”, segundo designação colonial portuguesa no Brasil, por exemplo), porém passíveis de serem integradas ao sistema de exploração econômica e assimiladas culturalmente; e 2) como populações culturalmente adversas ao projeto de implantação de um moderno Estado-nação e a própria modernização (as “sociedades contra o Estado” tal como concebidas por Pierre Clastres, por exemplo). Dito isto, temos que o poder tutelar ou a tutela coercitiva exercida sobre os povos indígenas são formas de racismo encoberto porque afirma discriminar os índios em seu próprio benefício, quando esta discriminação visa, ultimamente, sua (des)integração. Nestes termos, o “problema indígena” deve ser redefinido. Inicialmente, concebido como uma questão de integração sociocultural de segmentos populacionais “tradicionalistas” ao moderno Estado nacional:

“El 'problema indígena' se convirtió, pues, en un auténtico incordio político y teórico en América Latina. Para ser resuelto requeria, simultáneamente, ya que por su naturaleza el cambio en una de las dimensiones implicaba el de cada una de las otras: 1) la descolonización de las relaciones políticas dentro del Estado; 2) la subversión radical de las condiciones de explotación y el término de la servidumbre; 3) y como condición y punto de partida, la descolonización de las relaciones de dominación social, la expurgación de ‘raza’ como la forma universal y básica de clasificación social.” (2005b p. 20)

Portanto, para Quijano, a solução definitiva do “problema indígena” deveria implicar a subversão e desintegração, por completo, do padrão de poder secularmente estabelecido, mantido e internalizado pelos Estados nacionais nas formas de classificação oficial dos povos indígenas para fins de administração de suas necessidades e problemas. As soluções adotadas pelos governos latino-americanos, entretanto, foram outras.

Do assimilacionismo ao multiculturalismo constitucional na América Latina: A persistência da racialidade do poder na era dos direitos dos Povos Indígenas

A apresentação da genealogia conceitual sobre a mudança permite aprendermos os dois eixos em torno dos quais a interpretação antropológica de situações coloniais e de contato se desenvolveu. O primeiro eixo envolve a compreensão destas situações como o resultado histórico das relações de poder entre indígenas e europeus. O segundo eixo consiste na observação das dinâmicas internas desta estrutura de poder na produção e reprodução de ideologias de dominação específicas - ou modelos ideais de representação hierárquica da sociedade, como diria Leach - que asseguram a coesão da sociedade plural em meio a processos acentuadamente conflitivos e disruptivos. A contribuição de Balandier, seguida da guinada anti-colonialista promovida por antropólogos e sociólogos latino-americanos, permitiu elucidar a centralidade de concepções raciais como ideologia de estruturação social da diversidade étnica e cultural na região. É importante, neste momento, falar da interrelação existente entre colonialidade do poder e indigenismo como padrão de poder e ideologia de integração, respectivamente, se quisermos compreender porque a raça persiste como categoria operacional do Estado na relação com os povos indígenas. 
Como vimos desde os primeiros estudos antropológicos sobre a mudança cultural e depois, mais detidamente nas análises de Balandier, González Casanova e Quijano, o ponto comum definidor da “situação colonial”, do “colonialismo interno” e da “colonialidade do poder” é justamente a raça como princípio de organização das relações entre colonizadores e colonizados. Esta racialidade é responsável pela afirmação de superioridade de uma cultura superior (a dos colonizadores, depois tornada "nacional”) sobre outras culturas inferiores (a dos indígenas, depois transformados em minorias étnicas) e se traduz em ideologias, políticas, legislações, normas e práticas jurídicas e administrativas que legitimam a dominação como ato e processo "em benefício e proteção" dos colonizados. A expropriação territorial e a superexploração do trabalho são ressignificadas como ações civilizatórias diante das quais as populações indígenas, fatalistamente mais frágeis e vulneráveis, deveriam reconhecer como dadivosas. Esta realidade, para os autores mencionados, configura uma "situação", que agora seria melhor definida como um "complexo", pelo fato de se constituir e ser constitutiva de um sistema mundial de expansão e manutenção do capitalismo através de relações de interdependência entre países centrais e periféricos deste sistema.

O indigenismo como uma destas ideologias que expressam a racialidade do poder floresce na América Latina justamente com definições de “índio” como "grupos humanos representativos de estados de evolução e em vias de desaparecimento”, as quais colaboram com os projetos políticos e econômicos de unificação territorial e construção nacional dependente. Afinal, como nota Moraes (2008: 54), a situação do nacionalismo latino-americano seria o contrário da situação europeia, onde o problema principal era a criação de um território nacional para uma população considerada preexistente. A pergunta, nota Moraes, do projeto nacional brasileiro (assim como outros projetos americanos) era ao contrário: “com que povo contamos para construir o país.” (:94 apud Silva \& Lorenzoni 2012) Nesse sentido, as políticas indigenistas têm sido interpretadas basicamente como formas de assegurar o território demarcado pelo Estado a partir de políticas de integração (ou mudança dirigida) de populações culturalmente diversas na ordem nacional (Silva 2012).

Para uma melhor compreensão dos caminhos diversos que tomaram as concepções raciais na estruturação das múltiplas administrações indigenistas da região, deve-se considerar o lugar ambíguo ocupado pelo “índio” no imaginário da nação. Segundo Silva \& Lorenzoni:

“(...) o índio é ao mesmo tempo indígena no território, e alienígena na nação. Representando um estado primitivo, representa também a possibilidade de um processo evolutivo bem monitorado e planejado, livre dos vícios afetando a civilização ocidental. Portanto, além de primitivo, o índio se torna uma espécie de humano ideal no sentido de matéria-prima: argila para se formar. Nesse sentido, o índio também se torna uma tela de projeção para desejos nostálgicos de algo supostamente perdido pelo processo civilizatório, resultando em ambivalências entre idéias de 'preservação’ e assimilação. (...) Vemos, portanto, no indigenismo também um traço do que Rosaldo (1993) tem designado “nostalgia imperial”; o ato de lamentar a morte daquilo que o próprio tem condenado a morte (ou seja, a conservação na reserva, 
no museu, no parque ou no arquivo). Independente da ênfase em assimilação ou preservação é notável como se dá a erradicação de qualquer possibilidade dos próprios índios se articularem como sujeitos políticos e de direito dentro desse enquadramento.” (2012: 12)

Esta orientação tem perdurado por um século, pelo menos, através de políticas de integração orientadas para a assimilação das populações indígenas na América Latina segundo concepções contraditórias de proteção e assimilação - ambas sustentadas por leis, decretos, regulamentações e regimes tutelares, em que as reservas, resguardos e terras indígenas representaram a principal forma de exercer o governo indireto dessas populações. Vale dizer que esta contradição é apenas aparente, pois do ponto de vista das administrações indigenistas ela significa “proteção como meio de assimilação”.

É evidente que os povos indígenas não lidaram e não lidam com este processo de modo passivo. Os modos diversos como os movimentos indígenas procuraram, desde o período colonial e ao longo do século XX, assegurar sua autodeterminação e autonomia culminou no comprometimento, no final do século, das comunidades políticas dos Estados nacionais com o reconhecimento de seus direitos coletivos aos territórios tradicionais. O conjunto destas ações e pressões culminou em seções e artigos exclusivos voltados para os direitos dos povos indígenas nas cartas constitucionais nacionais dos anos 80 e 90 do século passado (Fajardo 2009) e que, mais recentemente, começaram a adquirir peso normativo em âmbito infraconstitucional (Berno de Almeida 2011) e até peso ideológico em projetos de refundação das instituições estatais, para não dizer do próprio Estado, como ocorre na Bolívia contemporânea (Schavelzon 2012).

As mobilizações políticas de indígenas, em diferentes momentos, regiões e países, assumiram um caráter anticolonialista e autonomista, o que não significa dizer separatista, o que se torna evidente quando examinados em escala regional e à contraluz das políticas neoliberais e dos grandes projetos de desenvolvimento econômico implementados na América Latina. Dito de outro modo, os indígenas passaram a ser reconhecidos como sujeitos coletivos de direitos e cidadãos plenos na maioria dos países do continente (Stavenhagen 2009). Esta realidade somente se mostrou possível em decorrência dos sucessivos movimentos indígenas, aliados a segmentos organizados da sociedade civil e da comunidade política, assim como utilizando o sistema internacional de direitos humanos, terem obrigado os governos locais, regionais e nacionais a reconhecer o direito de existirem como coletividades culturalmente diversas no interior destes países. Tratou-se de uma verdadeira política cultural antiracista acionada pelos movimentos indígenas junto aos Estados nacionais (ver Alvarez, Escobar e Dagnino 2000; Warren e Jackson 2002; Postero e Zamosc 2005; Oliveira 2008).

Entretanto, desde o reconhecimento em âmbito nacional e mundial dos direitos dos povos indígenas, nos anos 80 e 90, e agora, os fatores que teriam propiciado as reformas constitucionais na América Latina em prol dos povos indígenas parecem ter se provado episódicos à luz do caráter estruturante da racialidade do poder. ${ }^{\text {vii }}$ Se antes o que se buscava era projetar politicamente um novo ideal de modernidade através de uma nova carta de direitos sociais, políticos econômicos, de 
modo a que os países latino-americanos pudessem se realinhar, ao menos retoricamente, às concepções de direitos humanos e aos valores democráticos dos países ocidentais do norte e realizar a promessa do Estado nacional como promotor de igualdade e justiça social, o que a região enfrenta hoje é o dilema de conciliar esta "vontade de ser" com a "vontade de poder" des grupos e setores econômicos transnacionalizados por um sistema assolado por novas crises mundiais do capitalismo.

A defesa e promoção dos direitos territoriais e a autodeterminação dos povos indígenas sofrem hoje forte oposição política a partir de discursos raciais, como vimos inicialmente nas opiniões de Alan Garcia, que apenas ilustram o código neodesenvolvimentista compartilhado por outros dirigentes na região. ${ }^{\text {viii }}$ Discursos estes proferidos como atos performativos que visam acalmar os mercados com relação ao pacto econômico assumido por estes governos em detrimento do "impacto" que a defesa dos direitos sociais impõe à implementação dos empreendimentos. Nestes discursos temos que os povos indígenas são novamente concebidos como obstáculos aos projetos e programas de desenvolvimento e índices do atraso e da pobreza a serem superadas com o crescimento econômico. Seus conhecimentos e saberes tradicionais, em suma, uma parte significativa de suas culturas, são taxativamente desconsiderados, sem que se assegure uma relação simétrica com os povos que os detém (Carneiro da Cunha 2007), mas apenas como expressão de estágios atrasados de uma "mentalidade primitiva” que apenas alguns poucos antropólogos estruturalistas e perspectivistas seriam capazes de compreender e apreciar (ver crítica de Ramos 2012 a este respeito).

O multiculturalismo constitucional encontra-se abertamente ameaçado pela política econômica neoliberal e nededesenvolvimentista dos países da região. Esta vulnerabilidade decorre da própria fraqueza dos governos para promover a transformação das estruturas de dominação, dependentes que são dos setores interessados na manutenção de políticas neoliberais e neodesenvolvimentistas em nome de maior integração dos mercados latino-americanos na economia mundial. Nestes cenários, o multiculturalismo constitucional vem sendo "refuncionalizado" a partir de emendas constitucionais, projetos de lei, atos administrativos, decretos etc., que visam impedir que os direitos socioculturais constituam obstáculos à expansão econômica do capitalismo.

Dito isto, o que foi possível notar até o momento, é que o multiculturalismo enquanto política de Estado foi reduzido a uma resposta moral, de promoção de equidade e respeito entre grupos culturais ${ }^{\mathrm{ix}}$, ao invés de ser empregado como uma resposta a um problema político maior de redistribuição de poder e recursos entre grupos identitários e culturais, na maioria das vezes dominantes economicamente, sobre outros concebidos como racial ou etnicamente minoritários. Quer dizer, o multiculturalismo não chegou a enfrentar as estruturas de dominação provenientes das situações coloniais da região. Ele tem sido operacionalizado, basicamente, como um conjunto de políticas compensatórias de reconhecimento, reparação histórica e redistribuição de renda, onde o valor das “culturas indígenas” tem aí caráter meramente comercial para representação alegórica dos países latino-americanos como nações “culturalmente ricas”, para inglês ver, como se diz no Brasil. 
A presente conjuntura política e econômica latino-americana favorece assim a prática racializada do poder ao reduzir o multiculturalismo constitucional a um conjunto de enunciados vazios sobre o direito à diversidade. Isto se dá porque a diversidade cultural de grupos e povos distintivos para a constituição de uma unidade nacional multicultural não é traduzida em fortalecimento político destes grupos e povos, mas interpretada como impedimentos ao desenvolvimento da "nação”, representada aqui através de uma “identidade nacional” não só superior, mas soberana.

O principal problema operacional do multiculturalismo constitucional na América Latina, portanto, pode ser definido como sendo a fragilidade institucional do reconhecimento e proteção dos direitos socioculturais dos povos indígenas, dentre outros, face aos demais grupos, setores e interesses neoliberais e neodesenvolvimentistas da sociedade, amplamente representados no governo, no parlamento, no judiciário e nos meios de comunicação de massa e articulados de modo dependente ao capital transnacional global. Sob tal limitação dos direitos socioculturais, os povos indígenas deixam de ser reconhecidos horizontalmente como sujeitos políticos, mas apenas como clientes de políticas públicas específicas que visam “ajudá-los” a se desenvolver e ganhar autossuficiência (entenda-se, deixar de depender do Estado). Trata-se da atualização do discurso assimilacionista, agora com verniz multicultural.

A título de conclusão e para corroborar as interpretações acima, cabe realizar um rápido giro pelos estudos que têm se detido sobre o impacto das políticas neoliberais e neodesenvolvimentistas da região em um contexto de multiculturalismo constitucional. Pode-se depreender destes estudos quanto a contradição inerente ao padrão de dominação interétnica estabelecido desde os tempos coloniais tem dificultado, senão inviabilizado, reivindicações de autodeterminação e autonomia dos povos indígenas. Charles Hale (2002), por exemplo, afirma que o multiculturalismo na Guatemala apenas serviu para projetar o reconhecimento de um pacote mínimo de direitos coletivos para os povos indígenas diante das políticas-econômicas neoliberais definidas como prioritárias para o Estado-nação, engendrando um “multiculturalismo neoliberal” em que instituições poderosas que operam fora do Estado-nação exercem um poder direto sobre as ações governamentais. Christian Gros (2004), por sua vez, também problematiza o papel do multiculturalismo constitucional na Colômbia, no que tange a propiciar, de fato, maior autonomia local ou regional para os povos indígenas diante de pressões contrárias que desconfiam que autonomias indígenas coloquem em risco a coesão social, a centralização do poder estatal, a soberania territorial, além de maior inserção no mercado internacional. Em suas palavras:

“Este recelo frente a la creación de regiones autónomas se puede explicar por la voluntad de mantener un estricto control del territorio y de sus recursos (tierra, agua, bosque, biodiversidad, riquezas mineras) y, también, por el miedo legítimo de crear nuevas fronteras internas que podrían debilitar aún más la frágil unidad nacional. Pero más allá de estas razones, están las dudas a propósito de como, concretamente, podrían funcionar estas autonomías en regiones que, en su gran mayoría, serían de composición multiétnica y pluricomunitaria”. (2004:221) 
A desconfiança se transforma em acusação sobretudo quando as reivindicações de autodeterminação e autonomia política indígenas incidem sobre interesses estratégicos do governo em termos econômicos ou geopolíticos. Este problema se expressa sob a forma de um racismo institucional (Carmichael \& Hamilton 1967; Williams 1985) contra os povos indígenas, em que os baixos níveis de vida nas reservas e terras indígenas são acionados como "prova” ou "evidência” de que os indígenas são incapazes de resolver seus próprios problemas a despeito do aumento de recursos e políticas públicas multiculturais para eles.

No Equador, Floresmilo Simbaña (2005) descreve de forma resumida a situação em que se encontram os movimentos e povos indígenas entre os direitos conquistados e sua efetivação, realidade esta que pode ser encontrada nos demais países latino-americanos:

"El movimiento indígena ecuatoriano ha considerado la autodeterminación desde el derecho a la autonomía, es decir, Derecho de Autonomía de los pueblos y nacionalidades, respeto de los Derechos Indígenas en territorios indígenas al reconocimiento y oficialización de autoridades propias por parte de Estado.

La respuesta de los sectores del poder del sistema ecuatoriano va desde la deslegitimación y acusaciones de injerencias externas en el movimiento indígena, hasta pretensiones separatistas, antipatrióticas, peligrosas, arcaicas.” (:214)

No Brasil, Stephen Baines (2009) acompanhou diretamente o questionamento levantado contra a regularização definitiva da Terra Indígena Raposa/Serra do Sol no estado brasileiro de Roraima. Em seu artigo, após descrever o longo processo de identificação territorial e regularização fundiária das áreas indígenas próximas a região fronteiriça com a Guyana, diferentes segmentos da sociedade nacional e regional, militares, políticos, empresários, agricultores etc., buscaram formas legais e ilegais de "desconstituir” o direito de diferentes povos indígenas (Makuxi, Taurepang, Ingarikó, Patamona) a suas terras tradicionais. Segundo sua descrição:

"Foi uma surpresa para os povos indígenas que uma meia dúzia de rizicultores grileiros que ocuparam parte da Terra Indígena Raposa Serra do Sol em Roraima e vinham expandindo suas lavouras nos últimos anos, agredindo o ambiente com agrotóxicos, junto com alguns políticos e empresários de Roraima, tivessem pressionado o Governo Federal a colocar em julgamento a demarcação desta Terra Indígena, concluída em 1998, após décadas de luta por parte dos seus habitantes indígenas, e homologada pelo governo do Presidente Lula em abril de 2005. E ficaram ainda mais surpresos, após alguns destes rizicultores terem recorrido à violência contra os índios, burlando a lei e agindo com ameaças, táticas de guerrilha e agressões noticiadas pela imprensa.

(...) A situação reflete a contradição entre o Governo Federal, que implementa a 
políticaindigenistadoEstado, respaldadanaConstituição Federalde 1988, eosinteresses desenvolvimentistasdas elitesdoEstadodeRoraima,inimigostradicionaisdospovosindígenas.”(:32)

Por fim, cabe observar que em muitos casos, a resistência institucional dos Estados a adaptar-se ao horizonte multicultural das constituições se expressa de forma violenta com o desrespeito aos direitos dos povos indígenas e aos direitos humanos em defesa do desenvolvimento econômico e da integração nacional. Em Chiapas e Oaxaca no México, Lynn Stephen (1999) analisou a crescente militarização das relações entre Estado e povos indígenas nestas regiões de intensa mobilização das comunidades indígenas em prol de maior autonomia e participação política. A violência e abusos das forças militares e policiais na criminalização de lideranças e comunidades vinculadas aos movimentos indígenas e populares foi observada etnograficamente como um tipo de violência estatal que opera a partir de classificações étnicas e de gênero construídas na longa duração do colonialismo mexicano. Segundo Stephen:

“The gendered and ethnic dimensions of human rights abuses associated with high levels of militarization in Chiapas and Oaxaca reflect, in part,the cultural and ideological perspectives of those in the occupying forces of the army, Federal Judicial Police, and Public Security Police. These in turn are rooted in the processes of military conquest, Catholic conversion, and the mestizoization of Mexico during and since the colonial period. National stereotypes of indigenous peoples written into the myth and vision of Mexican history continue to be played out in contemporary strategies of conquest and militarization. Tactics aimed specifically at stripping Zapotec men of their masculinity, sexualizing them, and reducing them to feminine sexual equivalents on the part of male Federal Judicial Police agents echo the findings of researchers like Trexler(1995), discussed above. The casting of Tzotzil, Tzeltal, and Tojolabal women as whore-like Malinches, as an element of sexual disciplining suggests the importance of national myths in the self-legitimating ideology underlying the behavior of men in the army and police toward women. National gendered myths are part of the cultural scripts of rape.”(1999: 838)

Pelo exposto, o que os conceitos antropológicos e sociológicos sobre o padrão de poder colonial nos ensinam e estas análises da fragilidade do multiculturalismo constitucional frente às estruturas e processos de dominação interétnica demonstram é a atualização sistemática da racialidade do poder como forma de legitimar a violência dos projetos econômicos e políticos de grupos e setores dominantes da sociedade. Trata-se de uma forma de limitar a ascensão dos povos indígenas como sujeitos políticos no âmbito nacional, mantendo-os alheios aos processos e decisões políticos, mesmo quando estes os afetam diretamente. Este padrão de poder, como espero ter demonstrado teoricamente, vem a ser o principal obstáculo à efetivação dos direitos dos povos indígenas à autodeterminação, uma vez que segundo a lógica da razão colonial, tratam-se de populações racialmente inferiorizadas e como tais servem apenas para fins de exploração econômica e assimilação, e não como povos culturalmente diversos, detentores de outros projetos de sociedade e de desenvolvimento. 
Para Raquel Yrigoyen Fajardo, em 2009 quando se completam 20 anos da adoção do Convênio número 169 da Organização Internacional do Trabalho (OIT) ${ }^{\mathrm{x}}$, teríamos alcançado: “(...) um ponto de quebra do modelo de tratamento dos povos indígenas pelos Estados, ao reconhecer o seu direito de controlar as suas próprias instituições e definir suas prioridades de desenvolvimento, dando fim ao modelo de tutela indígena.” (Fajardo 2009: 11) À luz do que foi apresentado neste artigo, temos que a questão da autonomia indígena se impõe como um tema desafiante para a teoria política, mas principalmente, como desafio criativo para os movimentos indígenas que se veem diante da necessidade de transformar integralmente a cultura política dos Estados nacionais etnocráticos, i.e., controlados por uma etnicidade particular (Adams 1992: 181), para viabilizar de fato o fim da tutela. Para isto devemos aprender a provocar a autocrítica do e nos Estados, o que passa por uma crítica profunda da racialidade do poder ainda constitutiva dos mesmos. O primeiro passo neste sentido é continuar o trabalho de elaboração de conceitos que nos permitam compreender a razão colonial contemporânea a partir de etnografias que tomem a ação dos Estados com relação aos povos indígenas como fato social total das relações interétnicas.

\section{Bibliografia}

ADAMS, Richard, 1992: “Strategies of Ethnic Survival in Central America”. In: URBAN, Greg \& Joel SHERZER (eds.). Nation-States and Indians in Latin America. University of Texas Press, Austin: 181206.

AGUIRRE BELTRÁN, Gonzalo, 1991 [1967]: Regiones de Refugio: El desarrollo de la comunidad y el proceso dominical en mestizoamérica. Universidad Veracruzana/Instituto Nacional Indigenista/Gobierno el Estado de Veracruz/Fondo de Cultura Económica, México.

ALBERT, Bruce \& Alcida RAMOS (orgs.), 2002: Pacificando o branco: cosmologias do contato no norte-amazônico. Editora UNESP/Imprensa Oficial do Estado, São Paulo.

ALVAREZ, Sonia; Evelina DAGNINO \& Arturo ESCOBAR, Arturo (orgs.), 2000: Cultura e política nos movimentos sociais latino-americanos: novas leituras. Editora UFMG, Belo Horizonte.

BAINES, Stephen Grant, 2009: “Conflitos e reivindicações territoriais nas fronteiras: Povos Indígenas na Fronteira Brasil-Guiana”. In: SILVA, Cristhian Teófilo da Silva; Antonio Carlos de SOUZA LIMA \& Stephen BAINES (orgs.): Problemáticas Sociais para Sociedades Plurais: Políticas indigenistas, sociais e de desenvolvimento em perspectiva comparada. Annablume/FAP/DF, São Pauo \& Brasília: 27-43.

BAINES, Stephen Grant \& Cristhian Teófilo da SILVA, 2009: “Antropólogos, Usinas Hidrelétricas e Desenvolvimentalismo na América Latina”, Anuário Antropológico, v. 07-08: 271-297.

BALANDIER, Georges, 1966: “The Colonial Situation: A Theoretical Approach”. In: WALLERSTEIN, Immanuel (ed.). Social Change: The Colonial Situation. John Wiley \& Sons, New York, London, Sydney: 34-61. 
BARTH, Fredrik, 2000: “Os grupos étnicos e suas fronteiras”. In: LASK, Tomke (org.). O guru, o iniciador e outras variações antropológicas. Contra Capa Livraria: Rio de Janeiro.

BERNO DE ALMEIDA, Alfredo Wagner, 2011: “Os movimentos indígenas e a autoconsciência cultural - diversidade linguística e identidade coletiva”. Raízes, v. 33, n. 1, jan-jun.

BOAS, Franz, 2005: “Os objetivos da pesquisa antropológica”. In: CASTRO, Celso. Franz Boas: Antropologia Cultural. $2^{\text {a }}$ edição. Jorge Zahar Editor, Rio de Janeiro: 87-109.

BONFIL BATALLA, Guillermo et. al. 1982: América Latina: Etnodesarollo y Etnocídio. FLACSO, São José, Costa Rica.

CARDOSO DE OLIVEIRA, Roberto, 1998: O trabalho do antropólogo. Paralelo 15/Editora UNESP, Brasília \& São Paulo.

CARDOSO DE OLIVEIRA, Roberto, 1988: Sobre o pensamento antropológico. Tempo Brasileiro/ CNPq, Rio de Janeiro \& Brasília.

CARDOSO DE OLIVEIRA, Roberto, 1981 [1964]: O índio e o mundo dos brancos. $3^{\text {a }}$ edição, Editora Universidade de Brasília/Pioneira, Brasília \& São Paulo.

CARMICHAEL, S. \& HAMILTON, C.V.,1967: Black Power, Jonathan Cape.

CASTRO, Celso, 2005: Franz Boas: Antropologia Cultural. 2a edição, Jorge Zahar Editor, Rio de Janeiro.

CUNHA, Maria Manuela Ligeti Carneiro da, 2007: "Relações e dissensões entre saberes tradicionais e saber científicos”. Revista da Fundarte, v. 75.

ELIAS, Norbert, 1993: O processo civilizador, tomo 2. Jorge Zahar Editor, Rio de Janeiro.

EVENS, T. M. S. \& Don HANDELMAN (eds.), 2008: The Manchester School: Practice and ethnographic praxis in Anthropology. Berghahn Books, New York, Oxford.

FAJARDO, Raquel Z. Yrigoyen, 2009: “Aos 20 anos da Convenção 169 da OIT: balanço e desafios da implementação dos direitos dos Povos Indígenas na América Latina”. In: VERDUM, Ricardo (org.). Povos Indígenas: Constituições e Reformas Políticas na América Latina. INESC, Brasília: 11-62.

GLUCKMAN, Max, 1966: “Malinowski’s 'Functional’ Analysis of Social Change”. In: WALLERSTEIN, Immanuel (ed.). Social Change: The Colonial Situation. John Wiley \& Sons, New York, London, Sydney: 25-33. 
GONZÁLEZ CASANOVA, Pablo, 2007: “Colonialismo interno (uma redefinição)”. In: BORON, Atilio A.; Javier AMADEO \& Sabrina GONZALEZ (orgs.). A teoria marxista hoje. Problemas e perspectivas. <http://bibliotecavirtual.clacso.org.ar/ar/libros/campus/marxispt/cap. 19.doc > (site consulté le 8 novembre 2013)

GONZÁLEZ CASANOVA, Pablo, 1963: “Sociedad plural, colonialismo interno y desarrollo”. América Latina. Revista do Centro Latinoamericano de Ciencias Sociales (México) Ano VI, Nº 3, julho-setembro.

GROS, Christian, 2004: “Cuál autonomía para los pueblos indígenas de América Latina?” In: AROCHA, Jaime (comp.). Utopía para los excluídos: El multiculturalismo en África y América Latina. Facultad de Ciencias Humanas UN: 205-230.

HALE, Charles, 2002: “Does Multiculturalism Menace? Governance, Cultural Rights and the Politics of Identity in Guatemala”. Journal of Latin American Studies 34: 485-524.

JARVENPA, Robert, 1985: "The political economy and political ethnicity of American Indian adaptations and identities”. Ethnic and Racial Studies, Volume 8, Number 1, January: 29-48.

JIMENO, Myriam, 2005: “La vocación crítica de la Antropología en Latinoamérica”. Antípoda nº 1.

KYMLICKA, Will, 1996: Ciudadanía multicultural. Paidós, Barcelona, Buenos Aires \& México.

LEACH, Edmund, 1993 [1954]: Political Systems of Highland Burma. LSE, London.

L’ESTOILE, Benoit de; Federico NEIBURG \& Ligia SYGAUD, 2002: “Antropologia, impérios e estados nacionais: Uma abordagem comparativa”. In: L’ESTOILE, Benoit de; Federico NEIBURG \& Ligia SYGAUD (Orgs.). Antropologia, império e estados nacionais. Relume-Dumará, Rio de Janeiro: 9-37.

MALINOWSKI, Bronislaw, 1945: Dynamics of Culture Change. Yale University Press, New Haven.

MALINOWSKI, Bronislaw, 1966: “Theories of Culture Change”. In: WALLERSTEIN, Immanuel (ed.). Social Change: The Colonial Situation. John Wiley \& Sons, New York, London \& Sydney: 11-24.

MARROQUIN, Alejandro, 1977: Balance del indigenismo: informe sobre la política indigenista en américa. Instituto Indigenista Interamericano, ediciones especiales: 76, México.

MELATTI, Julio Cezar, 1979: “Pólos de articulação indígena”. Revista de Atualidade Indígena, Ano III, $\mathrm{n}^{\mathrm{o}} 18$, set./out., pp. 17-28. 
MORAES, Antonio Carlos Robert, 2004: Território e história no Brasil. Annablume, São Paulo.

OLIVEIRA, Adolfo de, 2008: Decolonising Indigenous Rights. Routledge, New York.

OLIVEIRA FILHO, João Pacheco de, 1998: “Uma etnologia dos 'índios misturados’? Situação colonial, territorialização e fluxos culturais”. Mana 4(1), pp. 47-77.

OLIVEIRA FILHO, João Pacheco de, 1988: “O Nosso Governo”: Os Ticuna e o regime tutelar. Marco Zero/MCT/CNPq, São Paulo \& Brasília.

OLIVEIRA, João Pacheco de \& Antonio Carlos de SOUZA LIMA, 1983: “Os muitos fôlegos do indigenismo”. Anuário Antropológico/81.

PEIRANO, Mariza, 1991: “The Anthropology of Anthropology: The Brazilian Case”. Série Antropologia nº 110, Universidade de Brasília, Brasília.

PINTO, Simone Rodrigues, 2008: “Multiculturalismo e Pluralismo Jurídico na América Latina”. Série Ceppac 014, Universidade de Brasília, Brasília.

PONTING, J. Rich \& Roger GIBBINS (eds.), 1980: Out of Irrelevance: A Socio-Political Introduction to Indian Affairs in Canada. Butterworths, Toronto.

POSTERO, Nancy Grey \& Leon ZAMOSC, 2005: La lucha por los derechos indígenas en América Latina. Abya-Yala: Quito.

QUIJANO, Aníbal, 2005a: “Colonialidade do poder, Eurocentrismo e América Latina”. In: LANDER, Edgardo (org.). A colonialidade do saber - Eurocentrismo e Ciências Sociais - Perspectivas latino-americanas. CLACSO, Buenos Aires: 227-275.

QUIJANO, Aníbal, 2005b: “El ‘Movimiento Indígena’ y las cuestiones pendientes en América Latina”. Revista Tareas, $n^{\circ}$ 119, enero-abril. CELA: 31-62.

RAMOS, Alcida, 2012: “The politics of perspectivism”. Annu. Rev. Anthropol., 41:481-94.

RAMOS, Alcida, 2011: “A Antropologia Brasileira no Mundo”. In: RIBEIRO, Gustavo Lins; Ana Maria FERNANDES, Carlos Benedito MARTINS \& Wilson TRAJANO FILHO (orgs.). As Ciências Sociais no Mundo Contemporâneo: Revisões e Prospecções. Letras Livres/Editora UnB, Brasília: 17-32.

RAMOS, Alcida, 2011: “Os direitos humanos dos povos indígenas no Bra sil”. In: MAYBURY-LEWIS, Biorn \& Sonia RANINCHESKI (orgs.) Desafios aos direitos humanos no Brasil Contemporâneo. CAPES/Verbena, Brasília: 65-80. 
RAMOS, Alcida, 1990: “Ethnology Brazilian Style”. Cultural Anthropology , Vol. 5, No. 4: 452-472.

REDFIELD, Robert, Ralph LINTON \& Melville J. HERSKOVITS, 1936: Memorandum for the Study of Acculturation (American Anthropologist, vol. 38: 149-152

RIBEIRO, Darcy, 1970: Os índios e a civilização: A integração das populações indígenas no Brasil moderno. Civilização Brasileira, Rio de Janeiro.

SCHADEN, Egon, 1976: Leituras de etnologia brasileira. Companhia Editora Nacional, São Paulo.

SCHAVELZON, Salvador, 2012: El nacimiento del Estado plurinacional de Bolivia. Etnografía de una Asamblea Constituyente. CLACSO/PLURAL/CEJIS/IWGIA, Buenos Aires.

SCHWARCZ, Lilia K. Moritz, 2005: “Questões de fronteira: Sobre uma antropologia da história”. Novos Estudos, n. 72, julho: 119-135.

SILVA, Cristhian Teófilo da, 2012: "Indigenismo como ideologia e prática de dominação: Apontamentos teóricos para uma etnografia do indigenismo latino-americano em perspectiva comparada”. Latin American Research Review, vol. 47 (1).

SILVA, Cristhian Teófilo da, 2003: “A Hermenêutica de Boas: elementos para uma releitura da matriz disciplinar da Antropologia”. Habitus, v.1, n.2, jul./dez.: 367-394.

SILVA, Cristhian Teofilo da \& Patricia LORENZONI, 2012: “A moldura positivista do indigenismo: A propósito do Estatuto do Índio para a proteção de povos indígenas no Brasil”, Série Ceppac 040.

SILVA, Cristhian Teófilo da Silva; Antonio Carlos de SOUZA LIMA \& Stephen BAINES (orgs.), 2009: Problemáticas Sociais para Sociedades Plurais: Políticas indigenistas, sociais e de desenvolvimento em perspectiva comparada. Annablume/FAP-DF, São Paulo \& Brasília.

SIMBAÑA, Floresmilo, 2005: “Plurinacionalidad y derechos colectivos: El caso ecuatoriano”. In: DÁVALOS, Pablo (comp.). Pueblos indígenas, Estado y Democracia. CLACSO, Buenos Aires.

SOUZA LIMA, Antonio Carlos de, 1995: Um grande cerco de paz. Vozes, Petrópolis.

STAVENHAGEN, Rodolfo, 2009: “Los nuevos derechos internacionales de los pueblos indígenas”. Anuário Antropológico/2007-2008: 61-86. 
STAVENHAGEN, Rodolfo, 1985: "Etnodesenvolvimento: Uma Dimensão Ignorada no Pensamento Desenvolvimentista”. Anuário Antropológico/84: 11-44.

STEPHEN, Lynn, 1999: "The construction of indigenous suspects: Militarization and the Gendered and Ethnic Dynamics of Human Rights Abuses in Southern Mexico”. American Ethnologist, Vol. 26, No. 4 (Nov.).

STOCKING Jr., George W. (org.), 2004: A formação da antropologia americana, 1883-1911. Contraponto/Editora UFRJ, Rio de Janeiro.

STOCKING Jr., George W. 1968: “Franz Boas and the Culture Concept in Historical Perspective”. In: STOCKING, George W. (ed.) Race, Culture and Evolution: Essays in the History of Anthropology. The Free Press, New York: 195-233.

SIGAUD, Lygia, 1996: “Introdução”. Sistemas Políticos da Alta Birmânia. EdUSP, São Paulo.

TRIGGER, Bruce, 1985: Natives and newcomers: Canada`s ‘Heroic Age’ reconsidered. McGill-Queen’s University Press, Montréal.

TROUILLOT, Michel-Rolph, 1991: “Anthropology and the Savage Slot: The Poetics and Politics of Otherness”. In: FOX, Richard (Ed.). Recapturing Anthropology. School of American Research Press, Sante Fe.

VIVEIROS DE CASTRO, Eduardo, 1999: “Etnologia Brasileira”. BIB - O que ler na Ciência Social brasileira (1970-1995)a. São Paulo: Ed. Sumaré, antropologia:109-223.

WARREN, Kay \& Jean JACKSON (eds.), 2002: Indigenous movements, self-representation, and the State in Latin America. The University of Texas Press, Austin.

WILLIAMS, J. 1985: “Redefining institutional racismo”. Ethnic and Racial Studies, 8:3: 323-348.

WOLF, Eric, 2010 [1982]: Europe and the People Without History. Berkeley \& Los Angeles: University of California Press. 
Situations coloniales, pluralisme ethnique et défis de l'autonomie autochtone en Amérique latine

Cristhian Teófilo da Silva

L’objectif de cet article est de présenter des concepts et des notions anthropologiques et sociologiques tirés des situations coloniales et des situations de contact afin d'expliquer la persistance de la notion de race dans l'exercice du pouvoir étatique sur les peuples autochtones à l'échelle des États nationaux de l’Amérique latine. Ce cadre conceptuel présente une lecture critique du multiculturalisme constitutionnel dans la région comme étant une tentative, uniquement rhétorique jusqu’à présent, pour surmonter ce modèle de domination et promouvoir les autonomies autochtones. L'auteur présente un débat critique sur les défis posés par la réalisation de l'autonomie autochtone en tant que projet effectif de décolonisation des sociétés postcoloniales de la région.

Mots clés: racialité du pouvoir, indigénisme, multiculturalisme, autonomie autochtone

\section{Colonial Situations, Ethnic Pluralism and Challenges to Indigenous Autonomy in Latin America}

Cristhian Teófilo da Silva

This article aims to present anthropological and sociological concepts developed under colonial and contact situations to explain the persistence of the notion of race in the exercise of State power over indigenous peoples within the national states of Latin America. This will enable a conceptual reference and a critical reading of the constitutional multiculturalism in the region as a rhetorical attempt so far to overcome this racial pattern of domination and promote indigenous autonomies. The author presents a critical debate around the challenges of indigenous autonomy as an effective decolonization project in the post-colonial societies of Latin America.

Keywords: raciality of power, Indigenism, Multiculturalism, Indigenous Autonomy

\section{Las situaciones coloniales, el pluralismo étnico y desafíos para la autonomía indígena en América} Latina

Cristhian Teófilo da Silva

El objetivo de este trabajo es presentar los conceptos antropológicos y sociológicos creados bajo las situaciones coloniales y las situaciones de contacto para explicar, según ellos, la persistencia de la noción de raza en el ejercicio del poder del Estado sobre los pueblos indígenas de América Latina. Esta revisión brindará una lectura crítica del multiculturalismo constitucional en la región como un intento sólo retórico para superar este modelo de dominación y promover las autonomías indígenas. El autor presenta un debate crítico sobre los problemas seculares para la realización de la autonomía indígena como un proyecto de descolonización efectivo de las sociedades postcoloniales en la región.

Palabras clave : Racialidad del poder, indigenismo, multiculturalismo, autonomía indígena

\section{Situações coloniais, pluralismo étnico e desafios da autonomia indígena na América Latina}

Cristhian Teófilo da Silva

Este trabalho tem como objetivo apresentar conceitos e noções antropológicos e sociológicos desenvolvidos em situações coloniais e de contato para explicar, através deles, a permanência da noção de raça no 
exercício do poder estatal sobre os povos indígenas no âmbito dos Estados nacionais latino-americanos. Este referencial conceitual permitirá esboçar uma leitura crítica do multiculturalismo constitucional na região como uma tentativa apenas retórica até o momento de superar este padrão de dominação e promover as autonomias indígenas. O objetivo é apresentar um debate crítico sobre os desafios seculares para a realização da autonomia indígena como um projeto de descolonização efetivo nas sociedades pós-coloniais na região.

Palavras-chave : Racialidade do poder, indigenismo, multiculturalismo, autonomias indígenas 


\section{Bio-biographical note}

Cristhian Teófilo da Silva, Doutor em Antropologia Social (Universidade de Brasília, 2005) é Professor Adjunto do Centro de Pesquisa e Pós-Graduação sobre as Américas e Pesquisador Associado do Centre Interuniversitaire d’Études et de Recherches Autochtones/Interuniversity Centre for Aboriginal Studies and Research (CIÉRA) da Université Laval (ULaval). Também é Conselheiro da seção Etnicidade, Raça e Povos Indígenas (ERIP) da Associação de Estudos Latino-Americanos (LASA) e membro da Comissão de Assuntos Indígenas (CAI) da Associação Brasileira de Antropologia (ABA). É fundador e coordenador do Grupo de Pesquisa (CNPq) e do Laboratório de Estudos e Pesquisas em Movimentos Indígenas, Políticas Indigenistas e Indigenismo (LAEPI). Atualmente, desenvolve pesquisa sobre autonomia indígena, políticas indigenistas e regimes de indianidade no Brasil e no Canadá. Possui quatro livros publicados no Brasil (dois como autor e dois como organizador) e artigos científicos, capítulos de livros e resenhas publicados na Argentina, Brasil, Canadá, Estados Unidos, México e Suécia.

Courriel: silvact@unb.br 


\section{Notas}

i. Para uma coletânea de estudos realizados no Brasil sob perspectiva semelhante ver Schaden 1976.

ii. Nesse sentido, ver Peirano 1991; Cardoso de Oliveira 1988 e 1998; Ramos 1990 e 2011 e Jimeno 2005. Para uma crítica dessa representação da etnologia, ver Viveiros de Castro 1999.

iii. Os conceitos aqui relacionados não esgotam o repertório existente sobre o tema. Caberia lembrar ainda as noções e conceitos de "pólos de articulação indígena” (Melatti 1979), "situação histórica” e “territorialização” (Oliveira Filho 1988 e 1998), “cosmologias do contato” (Albert e Ramos 2002) etc. De qualquer modo, estas e outras elaborações conceituais, mais ou menos simpáticas e até declaradamente adversárias das aqui mencionadas, dialogam com elas diretamente.

iv. González Casanova concordaria com tal genealogia, tal como explicitou em seu artigo de "redefinição do colonialismo interno" publicado em 2007 no qual afirma: “A análise correspondeu a esforços semelhantes que foram precedidos por C.Wright Mills (1963:154), quem de fato foi o primeiro a usar a expressão:'colonialismo interno'.’(s/p)

v. A partir desse momento, as teorias da mudança e do contato passariam a dialogar de modo mais direto e sistemático com as teorias do desenvolvimento nas Ciências Sociais. Valendo lembrar que sociólogos e economistas também passaram a se beneficiar dos estudos coloniais para elaborar suas "teorias da dependência” na América Latina, o que não significou de todo modo uma elaboração teórica adequada à superação dos valores implícitos às concepções de desenvolvimento empregadas pelos cientistas sociais como ferramentas de trabalho e mesmo de intervenção ou planejamento social (ver Stavenhagen 1985).

vi. Na verdade é dele a afirmação de que: "De hecho, raza es una categoría aplicada por primera vez a los “indios”, no a los “negros”. De este modo, raza apareció mucho antes que color en la historia de la clasificación social de la población mundial.”(2005a: 203)

vii. Vale lembrar que diversos países sequer reconhecem a problemática indígena no interior de suas constituições, para não dizer de suas fronteiras, a exemplo de Chile, França (entenda-se Guyane), Uruguai etc. (Pinto 2008 : 9)

viii. Para uma crítica ao "desenvolvimentismo” como expressão de um novo modelo de governabilidade criado na América Latina a partir de grandes projetos de infraestrutura ver Baines e Silva (2009).

ix. Nas palavras de Kymlicka: "Estoy hablando de minorías nacionales, es decir de grupos culturales y no de grupos raciales o ancestrales.” (1996 : 41)

x. Em fins dos anos 80 foi aprovada a Convenção 169 da OIT relativa aos povos indígenas e tribais em países independentes. Ela substituiu a Convenção 107 de 1957 que trazia um forte conteúdo assimilacionista. Os países que ratificaram a convenção foram: Argentina, Bolívia, Brasil, Colômbia, Costa Rica, Chile, Dominica, Equador, Fiji, Guatemala, Honduras, México, Nepal, Paraguai, Peru, Venezuela, Holanda, Noruega, Dinamarca e Espanha. Paradoxalmente, Canadá e EUA, na qualidade de berços do multiculturalismo, continuam sem ratificar a convenção. De qualquer modo, a aprovação do "Multiculturalism Act” no Canadá, da Convenção 169 da OIT, e das novas cartas constitucionais na América Latina em fins dos anos 80 e 90 do século XX denotam quanto se consolidou o consenso multiculturalista em torno da proteção dos povos indígenas não somente na América Latina, mas nas Américas e dentro do sistema de direitos humanos. 